\title{
Poly(1,5-Diaminonaphthalene)-Modified Screen-Printed Device for Electrochemical Lead Ion Sensing
}

\author{
Mai T. T. Nguyen $\mathbb{D}^{1},{ }^{1}$ Huy L. Nguyen $\mathbb{D}^{1},{ }^{1,2}$ and Dung T. Nguyen $\mathbb{D}^{2}$ \\ ${ }^{1}$ School of Chemical Engineering, Hanoi University of Science and Technology, 1 Dai Co Viet Road, Hanoi, Vietnam \\ ${ }^{2}$ Institute for Tropical Technology, Vietnam Academy of Science and Technology, 18 Hoang Quoc Viet Road, Hanoi, Vietnam \\ Correspondence should be addressed to Huy L. Nguyen; huy.nguyenle@hust.edu.vn and Dung T. Nguyen; ndung@itt.vast.vn
}

Received 5 November 2020; Revised 19 January 2021; Accepted 23 January 2021; Published 5 February 2021

Academic Editor: Viet Hai Le

Copyright (c) 2021 Mai T. T. Nguyen et al. This is an open access article distributed under the Creative Commons Attribution License, which permits unrestricted use, distribution, and reproduction in any medium, provided the original work is properly cited.

Poly(1,5-diaminonaphthalene) has been electropolymerized on the screen-printed device with a three-electrode configuration. The modified electrodes have been developed as the new electrode for electrochemical determination of trace levels of lead ions $\left(\mathrm{Pb}^{2+}\right)$. The poly(1,5-diaminonaphthalene) film prevents the deposition of $\mathrm{Pb}^{2+}$ into the surface defects of the bare carbon screen-printed electrode and possesses sensitivity to heavy metal ions thanks to amine and secondary amino groups on the polymer chain. The square wave anodic stripping voltammetry was applied to detect $\mathrm{Pb}^{2+}$ ions, showing a sharp stripping peak with the linear range from $0.5 \mu \mathrm{g} \cdot \mathrm{L}^{-1}$ to $5.0 \mu \mathrm{g} \cdot \mathrm{L}^{-1}\left(R^{2}=0.9929\right)$. The limit of detection was found to be $0.30 \mu \mathrm{g} \cdot \mathrm{L}^{-1}$. The sensors were applied to the analysis of $\mathrm{Pb}^{2+}$ in the tap water sample matrix with satisfactory results.

\section{Introduction}

At present, lead is one of the most critical toxic pollutants for biological systems. Lead is not biodegradable and accumulated in the food chain, so this metal remains a significant health concern. Exposure to even a low level of lead ions $\left(\mathrm{Pb}^{2+}\right)$ may cause severe damage to the brain and kidneys [1]. According to the stipulation of the European Union, the maximum allowable concentrations in food have been set to be from 0.02 to $1 \mathrm{mg} \cdot \mathrm{L}^{-1}$ [2], and as for the World Health Organization (WHO), it has been set as $10 \mu \mathrm{g} \cdot \mathrm{L}^{-1}$ for drinking water [3]. Due to these reasons, the rapid detection of $\mathrm{Pb}^{2+}$ at lower concentration levels is an important issue. A series of methods have been used for the detection of $\mathrm{Pb}^{2+}$, such as Atomic Absorption Spectroscopy (AAS) [4], Inductively Coupled Plasma Mass Spectroscopy (ICP-MS) [5], and X-Ray Fluorescence (XRF) spectrometry [6]. Using these methods, we can detect high accuracy and high sensitivity, but some disadvantages include bulky equipment size, expensive cost, a requirement of trained professionals, and large-scale analysis for indoor use. Besides, the electrochemistry method with the anodic stripping voltammetry (ASV) technique is also a powerful tool for detecting trace amounts of $\mathrm{Pb}^{2+}$. The advantages of the electroanalytical method are its rapid detection, small size, easy operation, and high sensitivity. The working electrodes based on the hanging drop mercury electrodes (HDME), dropping mercury electrodes (DME), and mercury film electrodes (MFE) have been widely reported during the past several decades [7]. However, mercury is toxic and unsuitable for portable devices. To date, there is a tendency to use the alternative of mercury electrodes (mercury-free) such as inorganic materials like bismuth [8], functionalized mesoporous silica [9], borondoped diamond [10], nanoscale carbon materials [11-13], and boron-doped diamond [14]. The polymer electrodes based on the conductive polymer film have been investigated toward metal ion detection with different approaches.

The conducting polymer's interesting features are its superior electrical conductivity, high specific surface area, good adhesion, and enhanced signal responses for target metal ions [15]. A large number of reports have shown that people used polymer composite electrodes for detection of $\mathrm{Pb}^{2+}$ such as polyaniline/carbon nanotubes [16], poly(vinylsulfonate)doped polyaniline [17], $p$-phenylenediamine [18], poly $(3,4-$ 

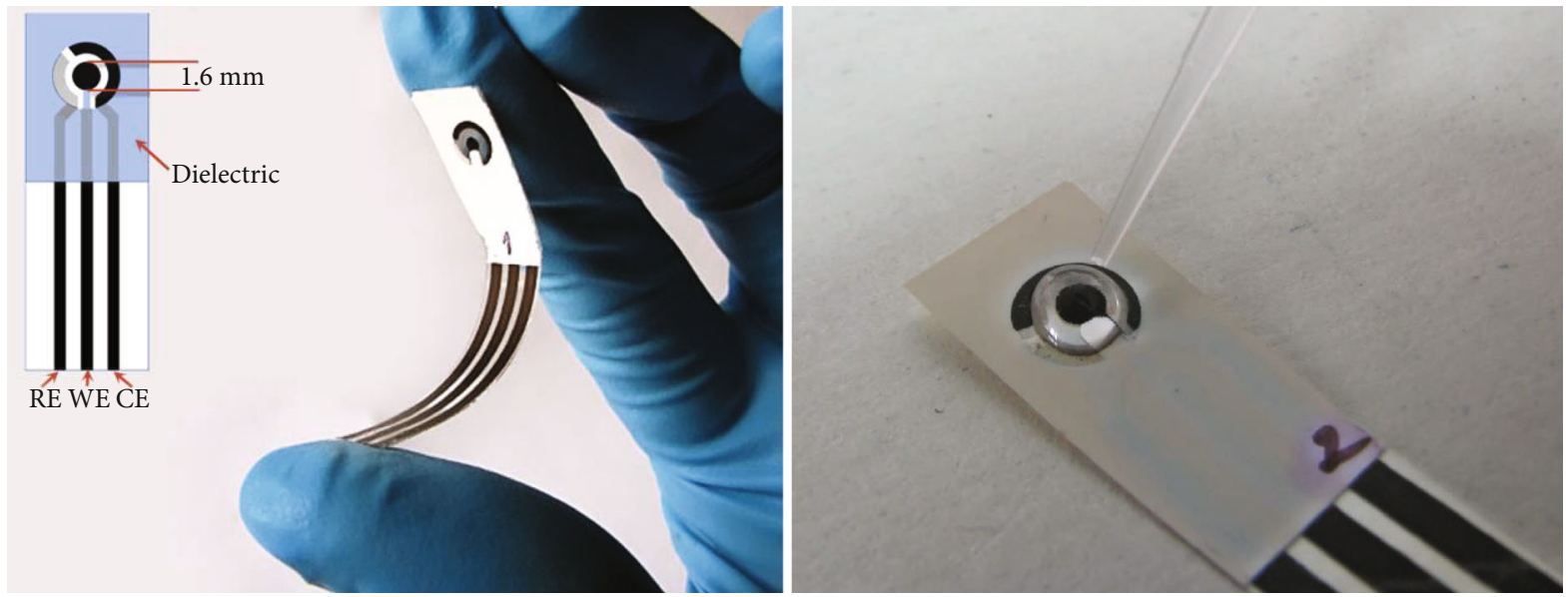

FIGURE 1: The illustration of the screen-printed devices with a three-electrode configuration.

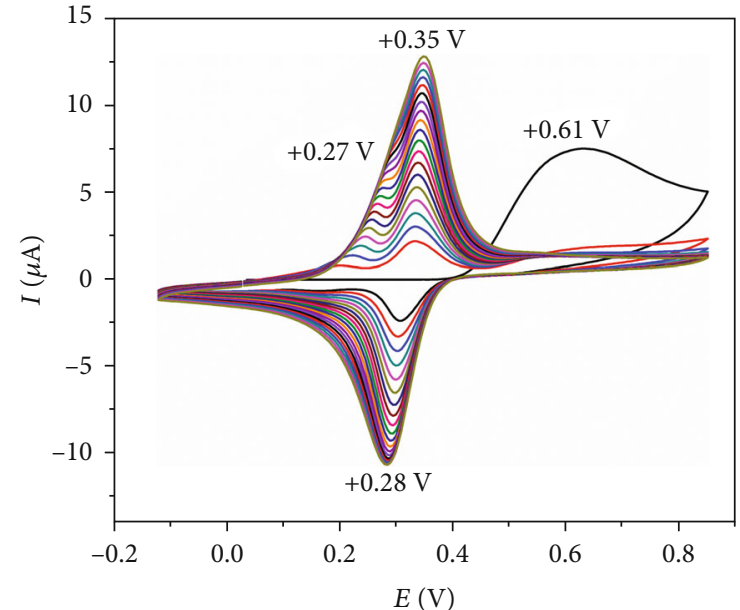

FIGURE 2: Cyclic voltammetric curves during $\mathrm{p}(1,5-\mathrm{DAN})$ film growth onto SPEs for 20 cycles. Solution: $1 \mathrm{mM}$ of 1,5-DAN and $0.1 \mathrm{M} \mathrm{LiClO}_{4}$ in $1 \mathrm{M} \mathrm{HClO}_{4}$; scan rate: $50 \mathrm{mV} \cdot \mathrm{s}^{-1}$.

ethylenedioxythiophene) [19], polypyrrole/carbon nanofibers [20], PEDOT/black $\mathrm{TiO}_{2}$ [21], and polydiaminonaphthalene $[22,23]$. Among these conducting polymers, poly $(1,5$-diaminonaphthalene) ( $\mathrm{p}(1,5-\mathrm{DAN}))$ has shown the capacity of collecting some metal ions because it possesses chelating properties and/or reduction properties owing to the electrondonating groups (amine and secondary amino groups) on the polymer chain [24]. Thus, $\mathrm{p}(1,5-\mathrm{DAN})$ could increase the stripping responses and the reproducibility for sensing.

Most of the work about polymer electrodes is based on the glassy carbon electrodes and carbon paste electrodes, which is not suitable for on-site applications. A screenprinted electrode emerged as a promising solution for this problem. The coupling of a screen-printed electrode with anodic stripping voltammetry (ASV) is more favorable in the heavy metal analysis due to the following: prepared in large quantities, rapid, inexpensive, flexible, and miniaturization. This study is aimed at preparing for a "lab-made" screen-printed device with a three-electrode configuration (consisting of the silver chloride pseudoreference electrode;

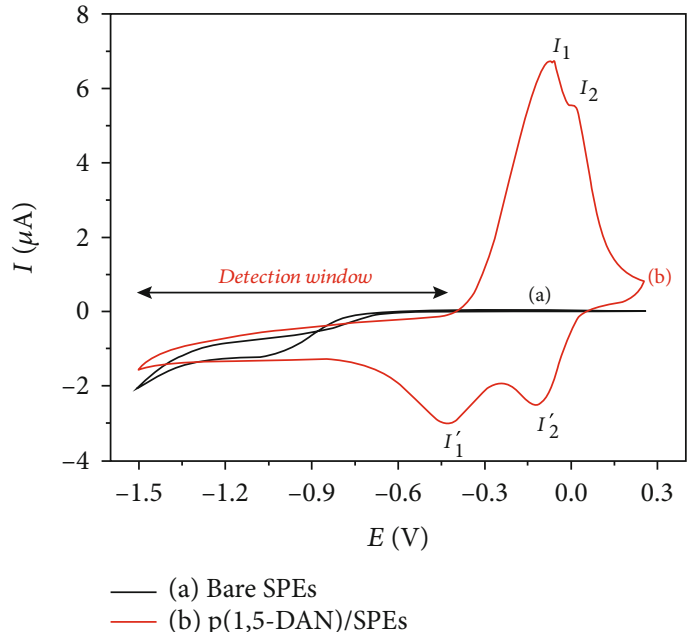

FIgure 3: CVs of bare SPEs (curve (a)) and p(1,5-DAN)/SPEs (curve (b)) in $0.1 \mathrm{M}$ acetate buffer ( $\mathrm{pH} 4.5$ ) with the scan rate of $50 \mathrm{mV} \cdot \mathrm{s}^{-1}$

carbon as a working electrode, and counter electrode) modified by $\mathrm{p}(1,5-\mathrm{DAN})$ for square wave anodic stripping voltammetry (SWASV) analysis of lead ions.

\section{Materials and Methods}

2.1. Reagents and Apparatus. 1,5-Diaminonaphthalene monomer, $\mathrm{LiClO}_{4}$, and $\mathrm{HClO}_{4}$ were obtained from SigmaAldrich. Lead solutions were prepared from a standard stock solution $\left(1,000 \mathrm{mg} \cdot \mathrm{L}^{-1}\right.$, atomic absorption standard solution, Scharlau Chemie). Sodium acetate buffer (0.1 M, pH 4.5), prepared by mixing an appropriate amount of $\mathrm{CH}_{3} \mathrm{COOH}$ and $\mathrm{CH}_{3} \mathrm{COONa}$, was used as a supporting electrolyte. All other reagents of analytical grade and deionized water were used throughout the experiments.

The bare screen-printed devices with a three-electrode configuration (SPEs) were fabricated on a polypropylene sheet substrate with a DEK Albany 247 printing machine (DEK, Weymouth, UK). These "lab-made" SPEs have dimensions about $1 \mathrm{~cm} \times 4 \mathrm{~cm}$ with a classical three-electrode system, 


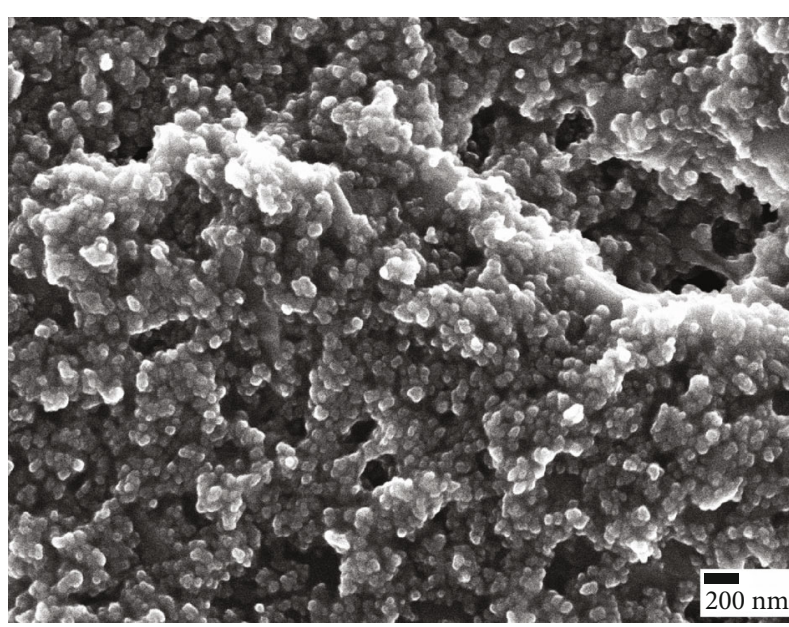

(a)

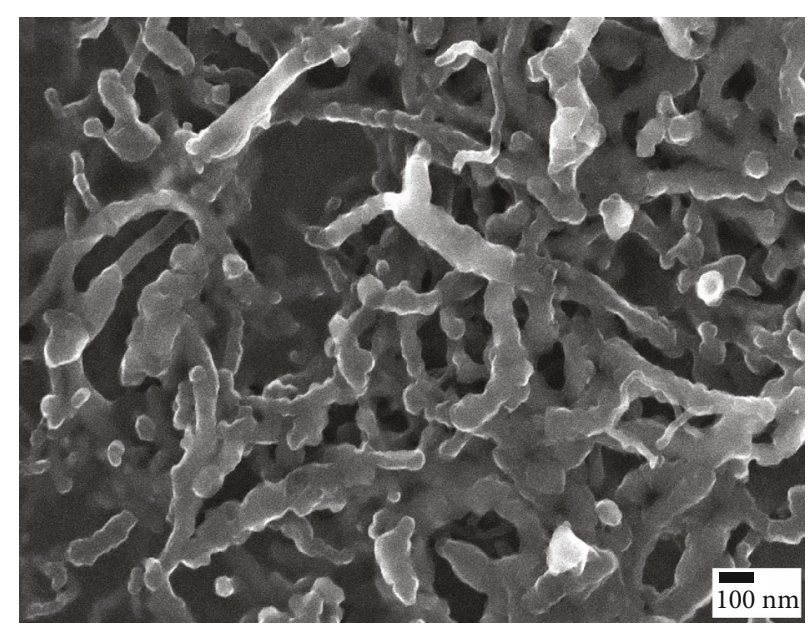

(b)

Figure 4: SEM image of (a) bare SPEs and (b) p(1,5-DAN)/SPEs.

including a silver chloride-based screen-printed pseudoreference electrode, carbon working electrode, and carbon counter electrode. The SPE fabrication process was described in our previous publication [25]. The working carbon electrode diameter was $1.6 \mathrm{~mm}$ in a geometric area of $0.02 \mathrm{~cm}^{2}$ with the thickness of coated layers of about $10 \mu \mathrm{m}$. The ratio counter electrode/working electrode surface area was $4 / 1$, and the silver chloride pseudoreference electrode with $E_{\text {ref. }} \approx+0.3 \mathrm{~V}$ and standard hydrogen electrode (SHE) are shown in Figure 1.

All electrochemical experiments were performed with an Autolab PGSTAT30 electrochemical analyzer (EcoChemie, the Netherlands) under the control of GPES version 4.9 data acquisition software. The electrochemical setup measurements were performed with the reaction solution's droplet $(15-50 \mu \mathrm{L})$ at room temperature $\left(\sim 25^{\circ} \mathrm{C}\right)$ and nondeaerated solutions. The morphology was observed by field emission scanning electron microscopy (FE-SEM; Hitachi S-4800).

2.2. SPEs Modified by $p(1,5-D A N)$. The $\mathrm{p}(1,5-\mathrm{DAN})$ film was electrochemically synthesized on SPEs in an aqueous solution consisting of the 1,5-diaminonaphthalene monomer with a concentration of $1.0 \mathrm{mM}$ and $0.1 \mathrm{M} \mathrm{LiClO}_{4}$ in a $1 \mathrm{M}$ $\mathrm{HClO}_{4}$ using cyclic voltammetry. The polymerization was performed in 20 cycles within the potential range from $-0.02 \mathrm{~V}$ to $+0.95 \mathrm{~V}$ with a sweep rate of $50 \mathrm{mV} \cdot \mathrm{s}^{-1}$. Afterward, the produced electrodes $\mathrm{p}(1,5-\mathrm{DAN}) / \mathrm{SPEs}$ were washed with deionized water.

2.3. Procedure for the SWASV Analysis. Square wave anodic stripping voltammetry is a frequently used anodic stripping voltammetry method because it can greatly reduce the background noise coming from the charging current during the potential scan [26]. The detection of $\mathrm{Pb}^{2+}$ was performed for various concentrations of $\mathrm{Pb}^{2+}$ in $0.1 \mathrm{M}$ acetate buffer ( $\mathrm{pH} 4.5$ ) using square wave voltammetry under the following conditions: frequency of $50 \mathrm{~Hz}$, amplitude of $50 \mathrm{mV}$, and step potential of $5 \mathrm{mV}$. The stripping voltammetric measurement procedure consisted of two steps: an accumulation step and a stripping step. Firstly, lead ions were deposited on the surface electrode at the negative potential for $180-480 \mathrm{~s}$.

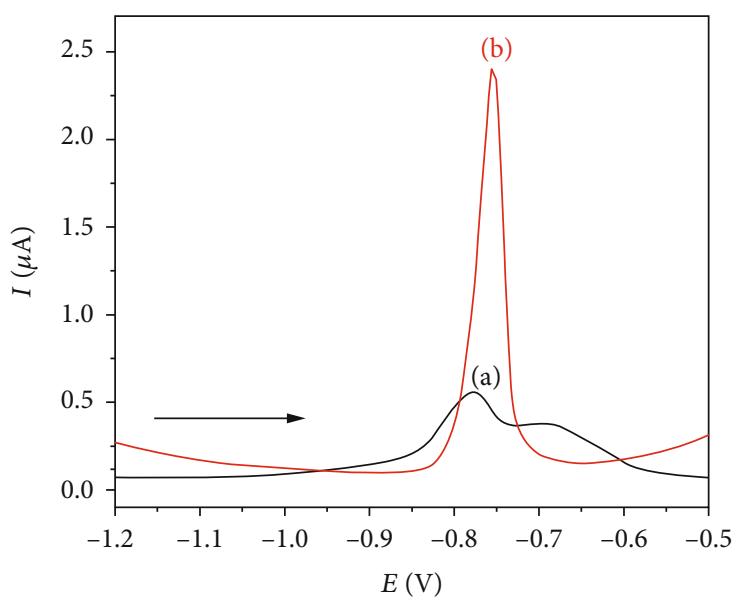

Figure 5: SWASV of $4.5 \mu \mathrm{g} \cdot \mathrm{L}^{-1} \mathrm{~Pb}^{2+}$ in acetate buffer ( $\mathrm{pH} 4.5$ ) at bare SPEs (a) and $\mathrm{p}(1,5-\mathrm{DAN}) / \mathrm{SPEs}$ (b). Deposition potential: $-1.2 \mathrm{~V}$; deposition time: $360 \mathrm{~s}$.

Then, the square wave anodic stripping voltammograms (SWASV) are recorded by applying a positive-going scan from -1.2 to $-0.5 \mathrm{~V}$.

\section{Results and Discussion}

3.1. Electropolymerization of $p(1,5-D A N)$ on the SPEs. Figure 2 displays the cyclic voltammograms between -0.02 and $+0.95 \mathrm{~V}$ at a scan rate of $50 \mathrm{mV} \cdot \mathrm{s}^{-1}$ taken during the electrochemical polymerization onto SPEs. In the first scan, the anodic peak at around $+0.61 \mathrm{~V}$ corresponds to the 1,5 -diaminonaphthalene monomer oxidation to the radical cation than the dication. In subsequent cycles, this peak seems to disappear, but at lower potentials, two anodic peaks are obtained at $+0.27 \mathrm{~V}$ and $+0.35 \mathrm{~V}$ and one cathodic peak at $+0.28 \mathrm{~V}$. The characteristic peaks characterized show electroactivity of $\mathrm{p}(1,5-\mathrm{DAN})$ in acid medium, and the current continuously increased during scans reflecting the growth of the conductive polymer film on the SPEs [23, 27-29]. 


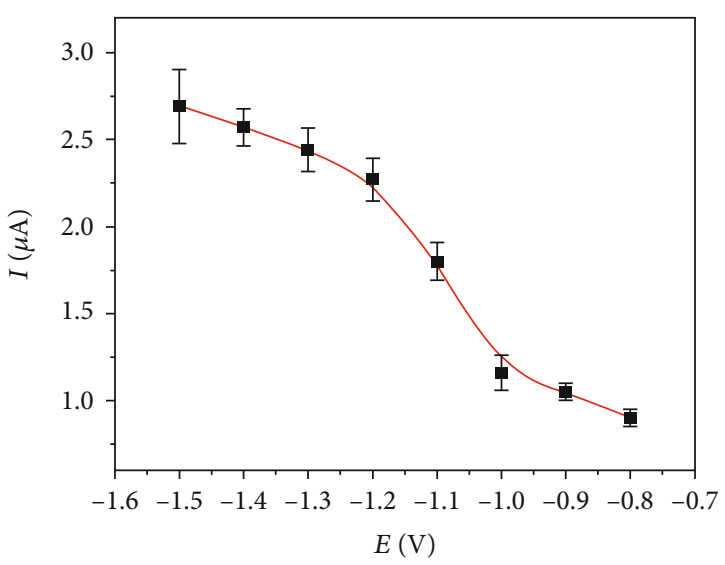

(a)

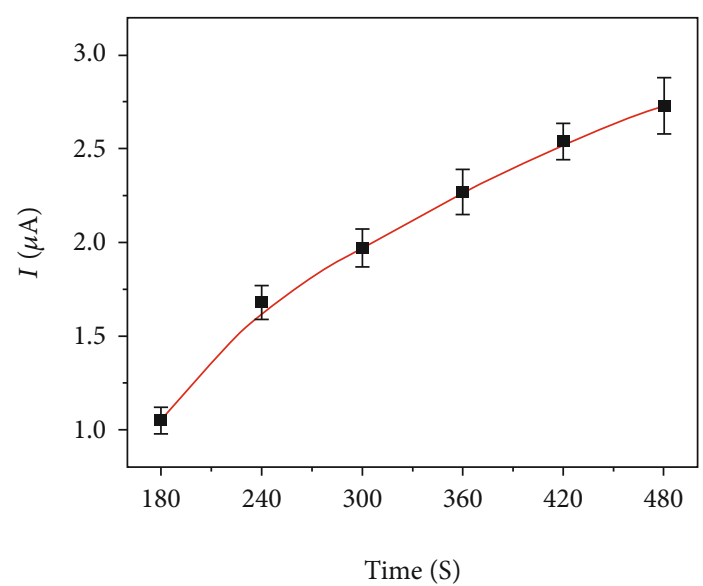

(b)

FIGURE 6: Effect of deposition potential (a) and deposition time (b) of $4.5 \mu \mathrm{g} \cdot \mathrm{L}^{-1} \mathrm{~Pb}^{2+}$ detection in acetate buffer ( $\mathrm{pH} 4.5$ ) on $\mathrm{p}(1,5$ DAN)/SPEs.

To confirm the successful polymerization of 1,5-diaminonaphthalene on SPEs, the electrodes were obtained by scanning the cyclic voltammograms in acetate buffer solution (pH 4.5) in the absence of the monomer. The cyclic voltammetry was performed between $-1.5 \mathrm{~V}$ and $+0.25 \mathrm{~V}$ at a scan rate of $50 \mathrm{mV} \cdot \mathrm{s}^{-1}$.

As shown in Figure 3, the cyclic voltammogram of $\mathrm{p}(1,5-$ DAN)/SPEs (curve (b)) has shown two typical redox couples $\left(I_{1} / I_{1}^{\prime}\right.$ and $\left.I_{2} / I_{2}^{\prime}\right)$ corresponding to doping and undoping of protons and anions in the $\mathrm{p}(1,5-\mathrm{DAN})$ film [28] clearly seen when compared with CVs of bare SPEs (curve (a)) under the same conditions. This result confirmed the successful polymerization of 1,5-DAN on screen-printed devices.

The working potential window's width is important for determining heavy metal ions with the anodic stripping voltammetry technique. As shown in Figure 3 (curve (b)), the voltammogram was almost straight from $-1.5 \mathrm{~V}$ to $-0.4 \mathrm{~V}$ (not affected by oxidation peaks of the polymer) and did not show an apparent influence of hydrogen evolution currents until $-1.5 \mathrm{~V}$. And the anodic peak for $\mathrm{Pb}^{2+}$ ion stripping is inside this potential range. That proves that the $\mathrm{p}(1,5-$ DAN)/SPEs are suitable for electrochemical determination of $\mathrm{Pb}^{2+}$ in acetate buffer electrolyte solution. The wide range of potential is promising for anodic stripping voltammetry of heavy metals such as $\mathrm{Zn}^{2+}, \mathrm{Cd}^{2+}$, and $\mathrm{Cu}^{2+}$.

3.2. Morphological Characteristics. The scanning electron microscope (SEM) morphologies of the bare SPEs and $\mathrm{p}(1,5-\mathrm{DAN}) / \mathrm{SPEs}$ were characterized by scanning electron microscopy, as shown in Figure 4. The bare carbon electrode was displayed with many dispersing small particles (Figure 4(a)). The small particles can be assigned as the carbon particles dispersed in a conductive screen printable ink. After electropolymerization, the morphology of the electrode changed significantly. The fabricated $\mathrm{p}(1,5-\mathrm{DAN})$ has a porous structure with a large active area and is homogeneously distributed throughout the electrode surface. The most widely accepted $\mathrm{p}(1,5-\mathrm{DAN})$ polymerization mechanism is the radical-mediated one, as reported in previous

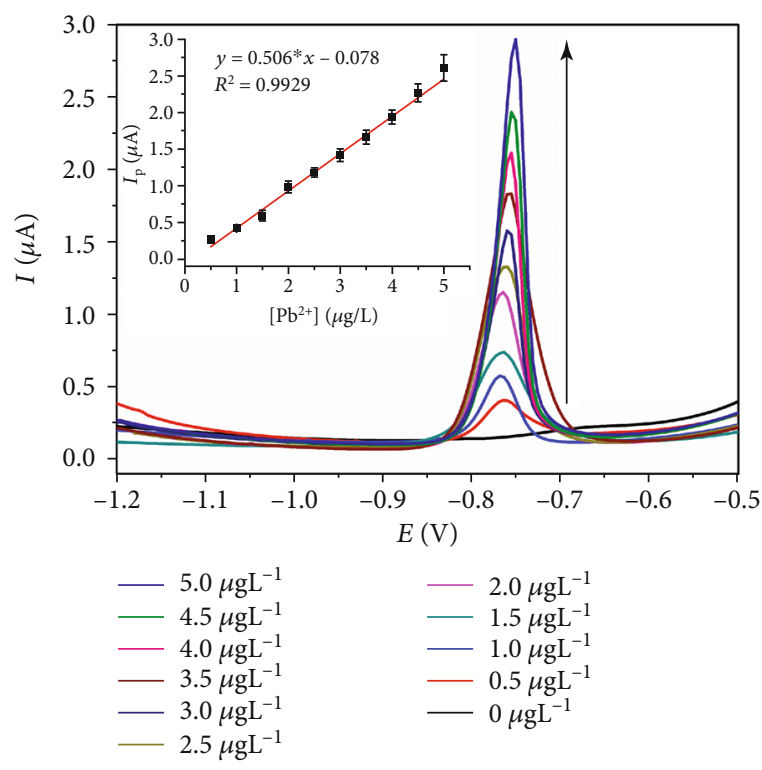

FIGURE 7: The SWASV response for the increasing concentration of $\mathrm{Pb}^{2+}$ in $0.5-5.0 \mu \mathrm{g} \cdot \mathrm{L}^{-1}$ and the corresponding calibration plots (inset) of $\mathrm{p}(1,5-\mathrm{DAN}) / \mathrm{SPEs}$. Electrolyte: acetate buffer $(\mathrm{pH} 4.5)$; deposition potential: $-1.2 \mathrm{~V}$; deposition time: $360 \mathrm{~s}$.

work [28-31]. In the initiation step, radical cations were generated from monomer oxidation by electrons on the anode. In the next steps, the radicals were then coupled to form oligomers and so on. However, the carbon screen-printed electrode has lower electron conductivity than the other electrodes (such as $\mathrm{Au}, \mathrm{Pt}$, and glassy carbon), which is attributed to the polymeric binder in the carbon ink [32]. The decrease in the electron transfer rate for screen-printed electrodes helps the formation of $\mathrm{p}(1,5-\mathrm{DAN})$-like nanowires at the low current density [33]. This film is suitable for the deposition of heavy metal ions in the preconcentration step.

3.3. The Application of $p(1,5-D A N) / S P E s$ for $\mathrm{Pb}^{2+}$ Sensors. Figure 5 shows the SWASV of $4.5 \mu \mathrm{g} \cdot \mathrm{L}^{-1} \mathrm{~Pb}^{2+}$ in acetate 
TABLE 1: Summary of publications relevant to the electrochemical detection of $\mathrm{Pb}^{2+}$ using conducting polymers.

\begin{tabular}{|c|c|c|c|c|}
\hline Electrode & Active layer & $\begin{array}{c}\mathrm{LOD} \\
\left(\mu \mathrm{g} \cdot \mathrm{L}^{-1}\right)\end{array}$ & $\begin{array}{l}\text { Linear range } \\
\left(\mu \mathrm{g} \cdot \mathrm{L}^{-1}\right)\end{array}$ & Ref. \\
\hline Glassy carbon & Poly(3,4-ethylenedioxythiophene)/black $\mathrm{TiO}_{2}$ composites & 0.15 & $8.28-256.93$ & [21] \\
\hline Sputtered planar platinum & Poly(1,5-diaminonaphthalene)/graphene & 0.02 & $0.2-700$ & [23] \\
\hline Glassy carbon & Polyaniline & 20.72 & $0-414.4$ & {$[34]$} \\
\hline Glassy carbon & $\begin{array}{l}\text { Overoxidized polypyrrole doped with 2(2-pyridylazo) } \\
\text { chromotropic acid anion }\end{array}$ & 10 & $0-200$ & [36] \\
\hline Planar platinum & $\begin{array}{l}\text { Interpenetrated multiwalled carbon nanotubes/poly } \\
\text { (1,5-diaminonaphthalene })\end{array}$ & 2.1 & $4-150$ & {$[37]$} \\
\hline Glassy carbon & Poly(1,2-diaminoanthraquinone) & 0.58 & $0-120$ & {$[38]$} \\
\hline Glassy carbon & \multirow{2}{*}{ Imidazole-functionalized polyaniline } & 20 & $2.07-2.07 \times 10^{5}$ & \multirow{2}{*}[39]{} \\
\hline Carbon paste & & 2 & $0.21-2.07 \times 10^{5}$ & \\
\hline Glassy carbon & Silver nanoparticles deposited on poly(1,8-diaminonaphthalene) & 0.031 & $207.2-2,486$ & {$[40]$} \\
\hline Glassy carbon & Polypyrrole-reduced graphene oxide nanocomposite hydrogels & 0.062 & $0.1-93.2$ & {$[41]$} \\
\hline Magnetic glassy carbon & Core-shell ferroferric oxide@polyaniline & 0.006 & $0.02-2,072$ & {$[42]$} \\
\hline Glassy carbon & Polyaniline-alanine-reduced graphene oxide & 0.009 & $0.016-20.72$ & {$[43]$} \\
\hline SPE & Graphene-polyaniline & 0.1 & $1-300$ & {$[44]$} \\
\hline SPE & Graphene/polyaniline/polystyrene & 3.3 & $10-500$ & {$[45]$} \\
\hline SPE & Poly(1,5-diaminonaphthalene) & 0.30 & $0.5-5.0$ & This work \\
\hline
\end{tabular}

buffer (pH 4.5) at bare SPEs (curve (a)) and $\mathrm{p}(1,5-$ DAN)/SPEs (curve (b)). The current response on bare SPEs is very poor, with a dwarf peak. Under identical conditions, the $\mathrm{p}(1,5-\mathrm{DAN})$-modified SPEs present significantly increased signals at $-0.75 \mathrm{~V}$.

The enhancement effects on the $\mathrm{p}(1,5-\mathrm{DAN}) / \mathrm{SPEs}$ are remarkably high in contrast to those on the bare SPEs. This result showed that $\mathrm{p}(1,5-\mathrm{DAN})$ was able to preconcentrate lead and was related to the amino and imine groups in the polymer chain. Besides, Wang et al. suggested that the conducting polymer has effectively prevented the adsorption of heavy metal ions on the microporous glassy carbon electrode [34]. So, almost all target ions are deposited on the electrode's surface, and the stripping voltammetry process is perfect.

3.4. Optimization of Conditions for $\mathrm{Pb}^{2+}$ Detection. In order to get the best of SWASV of the $\mathrm{p}(1,5-\mathrm{DAN}) / \mathrm{SPEs}$ toward $\mathrm{Pb}^{2+}$, some of the key parameters were selected for optimized experiments. The effect of deposition potential and deposition time of $\mathrm{Pb}^{2+}$ detection in $0.1 \mathrm{M}$ acetate buffer solution ( $\mathrm{pH} 4.5)$ was investigated and is shown in Figure 6.

As shown in Figure 6(a), the stripping peak current of $4.5 \mu \mathrm{g} \cdot \mathrm{L}^{-1} \mathrm{~Pb}^{2+}$ after $360 \mathrm{~s}$ of deposition increased when the deposition potential decreased. The peak current quickly increased as the deposition potential decreased to $-1.2 \mathrm{~V}$. The deposition potential decreased from -1.2 and $-1.5 \mathrm{~V}$, and the peak current increased but slower. However, to avoid possible interference with other metals and damage to the working electrode, the potential at $-1.2 \mathrm{~V}$ is chosen for continuous studies.

The effect of the deposition time for $45 \mu \mathrm{g} \cdot \mathrm{L}^{-1} \mathrm{~Pb}^{2+}$ detections on $\mathrm{p}(1,5-\mathrm{DAN}) / \mathrm{SPE}$ was studied in the range from 180 to $480 \mathrm{~s}$ (Figure 6(b)). Under a fixed deposition potential at $-1.2 \mathrm{~V}$, the peak current increased steadily with increasing deposition time. A $360 \mathrm{~s}$ deposition time was selected as a compromise between high signal and reasonable assay time.

3.5. Calibration Plot. The square wave peak current $\left(I_{\mathrm{p}}\right)$ for $\mathrm{Pb}^{2+}$ detection in $0.1 \mathrm{M}$ acetate buffer solution ( $\left.\mathrm{pH} 4.5\right)$ in the concentration range from $0.5 \mu \mathrm{g} \cdot \mathrm{L}^{-1}$ to $5.0 \mu \mathrm{g} \cdot \mathrm{L}^{-1}$ is shown in Figure 7. The peak current increases with an increase in the concentration of $\mathrm{Pb}^{2+}$ ions. The calibration curve (Figure 7, inset) was derived from the peak currents of SWASV curves that exhibit excellent linear dependence on the concentration of $\mathrm{Pb}^{2+}$ with a linearity regression equation $I_{\mathrm{p}}(\mu \mathrm{A})=0.506$ $\times C\left(\mu \mathrm{g} \cdot \mathrm{L}^{-1}\right)-0.078\left(R^{2}=0.9929\right)$. The limit of detection (LOD) was calculated by using the formula $\operatorname{LOD}=3.3 \times$ standard deviation of response/slope of the calibration curve [35]. The LOD obtained for the sensor was found to be $0.30 \mu \mathrm{g} \cdot \mathrm{L}^{-1}$.

In order to test the repeatability of sensors, the $\mathrm{p}(1,5$ DAN)/SPEs were used for five measurements of $4.5 \mu \mathrm{g} \cdot \mathrm{L}^{-1}$ $\mathrm{Pb}^{2+}$ in acetate buffer solution. The relative standard deviation ( $\% \mathrm{RSD}, n=5$ ) of $3.1 \%$ was found. This result suggests that the poly(1,5-diaminonaphthalene)-modified screenprinted device exhibited good reproducibility and stability toward the $\mathrm{Pb}^{2+}$ ion sensing.

The analytical performance of $\mathrm{p}(1,5-\mathrm{DAN}) / \mathrm{SPEs}$ for $\mathrm{Pb}^{2+}$ was compared with other reported conducting polymers based on the literature, and results are summarized in Table 1. As can be seen, almost all conducting polymers are usually combined with inorganic nanomaterials for sensor sensitivity enhancement. Comparisons showed that the poly(1,5-diaminonaphthalene)-modified screen-printed device is a potential sensor for electroanalysis of $\mathrm{Pb}^{2+}$ with a low LOD value.

3.6. Interferences of Other Metallic Ions. The interferences of some metallic ions on the detection of $\mathrm{Pb}^{2+}$ was investigated 
TABLE 2: Interferences of some metallic ions on the SWASV peak currents of $5.0 \mu \mathrm{g} \cdot \mathrm{L}^{-1} \mathrm{~Pb}^{2+}$.

\begin{tabular}{lcc}
\hline Interferent & Concentration $\left(\mu \mathrm{g} \cdot \mathrm{L}^{-1}\right)$ & Peak current change $(\%)$ \\
\hline $\mathrm{Zn}^{2+}$ & 500 & -0.4 \\
$\mathrm{Mn}^{2+}$ & 500 & +0.9 \\
$\mathrm{Fe}^{2+}$ & 500 & -2.6 \\
$\mathrm{Cu}^{2+}$ & 20 & +4.5 \\
$\mathrm{Al}^{3+}$ & 500 & -3.1 \\
$\mathrm{Hg}^{2+}$ & 8 & +15.7 \\
\hline
\end{tabular}

Electrolyte: acetate buffer ( $\mathrm{pH} 4.5$ ); deposition potential: $-1.2 \mathrm{~V}$; deposition time: $360 \mathrm{~s}$; frequency: $50 \mathrm{~Hz}$; amplitude: $50 \mathrm{mV}$; step potential: $5 \mathrm{mV}$.

TABle 3: Determination of $\mathrm{Pb}^{2+}$ in different tap water samples (mean of three determinations).

\begin{tabular}{lcccc}
\hline Sample & $\begin{array}{c}\text { Original } \\
\left(\mu \mathrm{g} \cdot \mathrm{L}^{-1}\right)\end{array}$ & $\begin{array}{c}\text { Add } \\
\left(\mu \mathrm{g} \cdot \mathrm{L}^{-1}\right)\end{array}$ & $\begin{array}{c}\text { Found } \\
\left(\mu \mathrm{g} \cdot \mathrm{L}^{-1}\right)\end{array}$ & $\begin{array}{c}\text { Recovery } \\
(\%)\end{array}$ \\
\hline $\begin{array}{l}\text { Tap water } \\
1\end{array}$ & Not detected & 2.0 & 1.98 & 94.5 \\
$\begin{array}{l}\text { Tap water } \\
2\end{array}$ & Not detected & 3.0 & 3.02 & 100.7 \\
$\begin{array}{l}\text { Tap water } \\
3\end{array}$ & Not detected & 4.0 & 4.05 & 101.2 \\
\hline
\end{tabular}

under the optimal experimental conditions discussed above. Table 2 suggests that some metallic ions, such as $\mathrm{Zn}^{2+}$, $\mathrm{Mn}^{2+}, \mathrm{Fe}^{2+}$, and $\mathrm{Al}^{2+}$ (each 100-fold excess) and $\mathrm{Cu}^{2+}$ (4-fold excess), did not influence the SWASV peak currents of $5.0 \mu \mathrm{g} \cdot \mathrm{L}^{-1} \mathrm{~Pb}^{2+}$ (the ratios for a $\pm 5 \%$ peak current change). For the concentration of $\mathrm{Hg}^{2+}\left(>8 \mu \mathrm{g} \cdot \mathrm{L}^{-1}\right)$, the anodic stripping peak currents of $\mathrm{Pb}^{2+}$ increase due to mercury ions that can be reduced and form a mercury film at the electrode surface.

3.7. Analysis of Lead Ions in Tap Water. The $\mathrm{p}(1,5-$ DAN)/SPEs were employed for the detection of $\mathrm{Pb}^{2+}$ in the tap water sample matrix. The $2 \mathrm{~mL}$ tap water sample was mixed well into a buffer solution ( $\mathrm{pH} 4.5)$ by sodium acetate and acetic acid, then dropped onto the $\mathrm{p}(1,5-\mathrm{DAN}) / \mathrm{SPEs}$ using a micropipette. The various concentrations of $\mathrm{Pb}^{2+}$ were spiked in the sample matrix. The SWASV was recorded under the optimum conditions. As can be seen in Table 3, the recoveries of $\mathrm{Pb}^{2+}$ were obtained with the concentration found divided by the assigned concentration of $\mathrm{Pb}^{2+}$ in the sample matrix. It is shown that the $\mathrm{p}(1,5-\mathrm{DAN}) / \mathrm{SPEs}$ are promising for the determination of $\mathrm{Pb}^{2+}$ in the real sample.

\section{Conclusions}

This work describes the use of the integrated screen-printed electrodes for the voltammetric determination of $\mathrm{Pb}^{2+}$ based on the poly(1,5-diaminonaphthalene) conductive polymer. The advantages of screen-printed electrodes, such as mass production, reproducibility, and ease of the preparation process, combined with a conductive polymer $\mathrm{p}(1,5-\mathrm{DAN})$, presented the excellent effect as a very inexpensive portable heavy metal ion analyzer. The modified screen-printed electrodes were used for the sensitive determination of $\mathrm{Pb}^{2+}$ by anodic stripping voltammetry.

\section{Data Availability}

The data used to support the findings of this study are included in the article.

\section{Conflicts of Interest}

The authors declare that there is no conflict of interest regarding the publication of this paper.

\section{Acknowledgments}

This work was financed by the grant-in-aid for scientific research from the Vietnam Academy of Science and Technology (VAST), code: NCVCC13.07/20-20.

\section{References}

[1] H. Needleman, "Lead poisoning," Annual Review of Medicine, vol. 55, no. 1, pp. 209-222, 2004.

[2] "Commission Regulation (EC) No 1881/2006 of 19 December 2006 setting maximum levels for certain contaminants in foodstuffs," 2006.

[3] WHO (WHO), "Guidelines for Drinking Water Quality," 2008.

[4] W. S. Zhong, T. Ren, and L. J. Zhao, "Determination of $\mathrm{Pb}$ (lead), Cd (cadmium), Cr (chromium), Cu (copper), and $\mathrm{Ni}$ (nickel) in Chinese tea with high-resolution continuum source graphite furnace atomic absorption spectrometry," Journal of Food and Drug Analysis, vol. 24, no. 1, pp. 46-55, 2016.

[5] H. P. Longerich, B. J. Fryer, and D. F. Strong, "Determination of lead isotope ratios by inductively coupled plasma-mass spectrometry (ICP-MS)," Spectrochimica Acta Part B: Atomic Spectroscopy, vol. 42, no. 1-2, pp. 39-48, 1987.

[6] M. Ali, T. R. Choudhury, B. Hossain, and M. P. Ali, "Determination of traces of molybdenum and lead in foods by X-ray fluorescence spectrometry," SpringerPlus, vol. 3, no. 1, 2014.

[7] J. Barek, A. G. Fogg, A. Muck, and J. Zima, "Polarography and voltammetry at mercury electrodes," Critical Reviews in Analytical Chemistry, vol. 31, no. 4, pp. 291-309, 2001.

[8] J. Wang, "Stripping analysis at bismuth electrodes: a review," Electroanalysis, vol. 17, no. 15-16, pp. 1341-1346, 2005.

[9] N. Cotolan, L. M. Mureşan, A. Salis, L. Barbu-Tudoran, and G. L. Turdean, "Electrochemical detection of lead ions with ordered mesoporous silica-modified glassy carbon electrodes," Water, Air, \& Soil Pollution, vol. 231, no. 5, 2020.

[10] J. H. T. Luong, K. B. Male, and J. D. Glennon, "Boron-doped diamond electrode: synthesis, characterization, functionalization and analytical applications," Analyst, vol. 134, no. 10, pp. 1965-1979, 2009.

[11] A. K. Wanekaya, "Applications of nanoscale carbon-based materials in heavy metal sensing and detection," Analyst, vol. 136, no. 21, pp. 4383-4391, 2011.

[12] S. Arora, M. K. Punith Kumar, and C. Srivastava, "Graphene$\mathrm{ZnO}$ nanocomposite sensor for lead-ion detection," Philosophical Magazine Letters, vol. 100, no. 11, pp. 533-541, 2020. 
[13] K. Wu, S. Hu, J. Fei, and W. Bai, "Mercury-free simultaneous determination of cadmium and lead at a glassy carbon electrode modified with multi-wall carbon nanotubes," Analytica Chimica Acta, vol. 489, no. 2, pp. 215-221, 2003.

[14] T. M. Arantes, A. Sardinha, M. R. Baldan, F. H. Cristovan, and N. G. Ferreira, "Lead detection using micro/nanocrystalline boron-doped diamond by square-wave anodic stripping voltammetry," Talanta, vol. 128, pp. 132-140, 2014.

[15] V. Sethumadhavan, S. Rudd, E. Switalska, K. Zuber, P. Teasdale, and D. Evans, "Recent advances in ion sensing with conducting polymers," BMC Materials, vol. 1, no. 1, 2019.

[16] Z. Wang, E. Liu, D. Gu, and Y. Wang, "Glassy carbon electrode coated with polyaniline-functionalized carbon nanotubes for detection of trace lead in acetate solution," Thin Solid Films, vol. 519, no. 15, pp. 5280-5284, 2011.

[17] J. H. Santos, M. R. Smyth, and R. Blanc, "Mercury-free anodic stripping voltammetry of lead ions using a PVS-doped polyaniline modified glassy carbon electrode," Analytical Communications, vol. 35, no. 10, pp. 345-348, 1998.

[18] I. Adraoui, M. el?Rhazi, A. Amine, L. Idrissi, A. Curulli, and G. Palleschi, "Lead determination by anodic stripping voltammetry using ap-Phenylenediamine modified carbon paste electrode," Electroanalysis, vol. 17, no. 8, pp. 685-693, 2005.

[19] P. Manisankar, C. Vedhi, G. Selvanathan, and P. Arumugam, "Differential pulse stripping voltammetric determination of heavy metals simultaneously using new polymer modified glassy carbon electrodes," Microchimica Acta, vol. 163, no. 34, pp. 289-295, 2008.

[20] L. Oularbi, M. Turmine, and M. El Rhazi, "Electrochemical determination of traces lead ions using a new nanocomposite of polypyrrole/carbon nanofibers," Journal of Solid State Electrochemistry, vol. 21, no. 11, pp. 3289-3300, 2017.

[21] Z. Yu, R. Jamal, R. Zhang et al., "PEDOT-type conducting polymers/black TiO2Composites for electrochemical determination of $\mathrm{Cd}^{2+}$ and $\mathrm{Pb}^{2+}$," Journal of The Electrochemical Society, vol. 167, no. 6, article 067514, 2020.

[22] S. Majid, M. E. Rhazi, A. Amine, A. Curulli, and G. Palleschi, "Carbon paste electrode bulk-modified with the conducting polymer poly(1,8-diaminonaphthalene): application to lead determination," Microchimica Acta, vol. 143, no. 2-3, pp. 195-204, 2003.

[23] T. D. Nguyen, T. T. H. Dang, H. Thai et al., "One-step electrosynthesis of poly(1,5-diaminonaphthalene)/graphene nanocomposite as platform for lead detection in water," Electroanalysis, vol. 28, no. 8, pp. 1907-1913, 2016.

[24] X.-G. Li, J.-L. Zhang, and M.-R. Huang, "Chemical response of nanocomposite membranes of electroactive polydiaminonaphthalene nanoparticles to heavy metal ions," The Journal of Physical Chemistry C, vol. 118, no. 22, pp. 11990-11999, 2014.

[25] H. L. Nguyen, H. H. Cao, D. T. Nguyen, and V.-A. Nguyen, "Sodium dodecyl sulfate doped polyaniline for enhancing the electrochemical sensitivity of mercury ions," Electroanalysis, vol. 29, no. 2, pp. 595-601, 2017.

[26] X. S. Zhu, C. Gao, J.-W. Choi, P. L. Bishop, and C. H. Ahn, "On-chip generated mercury microelectrode for heavy metal ion detection," Lab on a Chip, vol. 5, no. 2, pp. 212-217, 2005.

[27] S. K. Yadav, B. Agrawal, and R. N. Goyal, "AuNPs-poly-DAN modified pyrolytic graphite sensor for the determination of cefpodoxime proxetil in biological fluids," Talanta, vol. 108, pp. 30-37, 2013.
[28] M. C. Pham, M. Oulahyne, M. Mostefai, and M. M. Chehimi "Multiple internal reflection FT-IR spectroscopy (MIRFTIRS) study of the electrochemical synthesis and redox process of poly (1,5-diaminonaphthalene)," Synthetic Metals, vol. 93, no. 2, pp. 89-96, 1998.

[29] V. A. Nguyen, H. L. Nguyen, D. T. Nguyen, Q. P. Do, and L. D. Tran, "Electrosynthesized poly(1,5-diaminonaphthalene)/polypyrrole nanowires bilayer as an immunosensor platform for breast cancer biomarker CA 15-3," Current Applied Physics, vol. 17, no. 11, pp. 1422-1429, 2017.

[30] K. Jackowska, J. Bukowska, and M. Jamkowski, "Synthesis, electroactivity and molecular structure of poly(1,5-diaminonaphthalene)," Journal of Electroanalytical Chemistry, vol. 388, no. 1-2, pp. 101-108, 1995.

[31] M. C. Pham, M. Oulahyane, M. Mostefai, and P. C. Lacaze, "Electrosynthesis and in situ multiple internal reflection FTIR spectroscopic (MIRFTIRS) study of poly( 1,5-diaminonaphthalene)," Synthetic Metals, vol. 84, no. 1-3, pp. 411-412, 1997.

[32] K. Grennan, A. J. Killard, and M. R. Smyth, "Physical characterizations of a screen-printed electrode for use in an amperometric biosensor system," Electroanalysis, vol. 13, no. 8-9, pp. 745-750, 2001.

[33] L. Liang, J. Liu, C. F. Windisch, Jr, G. J. Exarhos, and Y. Lin, "Direct assembly of large arrays of oriented conducting polymer nanowires," Angewandte Chemie International Edition, vol. 41, no. 19, pp. 3665-3668, 2002.

[34] Z. Wang, E. Liu, and X. Zhao, "Glassy carbon electrode modified by conductive polyaniline coating for determination of trace lead and cadmium ions in acetate buffer solution," Thin Solid Films, vol. 519, no. 15, pp. 5285-5289, 2011.

[35] A. Shrivastava and V. B. Gupta, "Methods for the determination of limit of detection and limit of quantitation of the analytical methods," Chronicles of Young Scientists, vol. 2, no. 1, pp. 21-25, 2011.

[36] A. Wanekaya and O. A. Sadik, "Electrochemical detection of lead using overoxidized polypyrrole films," Journal of Electroanalytical Chemistry, vol. 537, no. 1-2, pp. 135-143, 2002.

[37] H. D. Vu, L.-H. Nguyen, T. D. Nguyen, H. B. Nguyen, T. L. Nguyen, and D. L. Tran, "Anodic stripping voltammetric determination of $\mathrm{Cd}^{2+}$ and $\mathrm{Pb}^{2+}$ using interpenetrated MWCNT/P1,5-DAN as an enhanced sensing interface," Ionics, vol. 21, no. 2, pp. 571-578, 2015.

[38] K. M. Hassan, S. E. Gaber, M. F. Altahan, and M. A. Azzem, "Novel sensor based on poly (1,2-diaminoanthraquinone) for individual and simultaneous anodic stripping voltammetry of $\mathrm{Cd}^{2+}, \mathrm{Pb}^{2+}, \mathrm{Cu}^{2+}$ and $\mathrm{Hg}^{2+}$, Electroanalysis, vol. 30, no. 6, pp. 1155-1162, 2018.

[39] P. Kumar, A. Joseph, P. C. Ramamurthy, and S. Subramanian, "Lead ion sensor with electrodes modified by imidazolefunctionalized polyaniline," Microchimica Acta, vol. 177, no. 3-4, pp. 317-323, 2012.

[40] K. M. Hassan, G. M. Elhaddad, and M. AbdelAzzem, "Voltammetric determination of cadmium(II), lead(II) and copper(II) with a glassy carbon electrode modified with silver nanoparticles deposited on poly(1,8-diaminonaphthalene)," Microchimica Acta, vol. 186, no. 7, 2019.

[41] V. Suvina, S. M. Krishna, D. H. Nagaraju, J. S. Melo, and R. G. Balakrishna, "Polypyrrole-reduced graphene oxide nanocomposite hydrogels: a promising electrode material for the simultaneous detection of multiple heavy metal ions," Materials Letters, vol. 232, pp. 209-212, 2018. 
[42] Y. Kong, T. Wu, D. Wu et al., "An electrochemical sensor based on Fe3O4@PANI nanocomposites for sensitive detection of $\mathrm{Pb}^{2+}$ and $\mathrm{Cd}^{2+}$," Analytical Methods, vol. 10, no. 39, pp. 4784-4792, 2018.

[43] M. Akhtar, A. Tahir, S. Zulfiqar et al., "Ternary hybrid of polyaniline-alanine-reduced graphene oxide for electrochemical sensing of heavy metal ions," Synthetic Metals, vol. 265, article 116410, 2020.

[44] N. Ruecha, N. Rodthongkum, D. M. Cate, J. Volckens, O. Chailapakul, and C. S. Henry, "Sensitive electrochemical sensor using a graphene-polyaniline nanocomposite for simultaneous detection of $\mathrm{Zn}(\mathrm{II}), \mathrm{Cd}(\mathrm{II})$, and $\mathrm{Pb}(\mathrm{II})$," Analytica Chimica Acta, vol. 874, pp. 40-48, 2015.

[45] N. Promphet, P. Rattanarat, R. Rangkupan, O. Chailapakul, and N. Rodthongkum, "An electrochemical sensor based on graphene/polyaniline/polystyrene nanoporous fibers modified electrode for simultaneous determination of lead and cadmium," Sensors and Actuators B: Chemical, vol. 207, pp. 526-534, 2015. 